\title{
Ion Exchange Properties of Japanese Natural Zeolites in Seawater
}

\author{
Takaaki WAJIMA \\ Department of Applied Chemistry, Graduate School of Engineering and Resource Science, Akita University, \\ 1-1 Tegata-gakuen, Akita 010-8502, Japan
}

\begin{abstract}
Ion exchange properties of five different Japanese natural zeolites in seawater were examined. Sodium ions could be reduced by all zeolites, although anions, $\mathrm{Cl}^{-}$and $\mathrm{SO}_{4}{ }^{2-}$, in seawater showed barely changes. Natural zeolite desalination treatment mainly depends on the ion exchange between $\mathrm{Na}^{+}, \mathrm{K}^{+}$and $\mathrm{Mg}^{2+}$ in seawater and $\mathrm{Ca}^{2+}$ in natural zeolite. This study found that mordenite is superior to clinoptilolite for use in $\mathrm{Na}^{+}$reduction. Mordenite with high cation exchange capacity containing $\mathrm{Ca}^{2+}$ resulted in the highest $\mathrm{Na}^{+}$reduction from seawater.
\end{abstract}

(Received August 30, 2012; Accepted October 16, 2012; Published January 10, 2013)

\section{Introduction}

Seawater desalination is an important technology for water utilization. Desalination technologies such as the multi stage flash (MSF) method, reverse osmosis (RO) method and electrodialysis, are well known,,$^{1-3}$ but these technologies have a large footprint and are expensive for agricultural use. There are many rural areas all over the world that only have access to saline water and salted soil. Cultivated lands in northeast Japan have also been damaged by tsunamis, resulting in salted soil that is not suitable for use in agriculture. For agricultural purposes, there is a great need for simple and inexpensive techniques for decreasing the salinity of saline water or salted soil.

Natural zeolites occur in natural deposits, generally associated with grassy volcanic rock, and are available in large quantities at low cost. ${ }^{4-6}$ Because of their high ion-exchange capacity, absorptivity, water retention and low cost, natural zeolites have been used in agronomy, horticulture and various other industries..$^{7-12}$ In earlier studies, a simple method to reduce $\mathrm{NaCl}$ concentration in seawater using natural zeolite treatment combined with calcined hydrotalcite treatment was attempted, and radish sprouts were grown in the resulting solution. ${ }^{13-17}$ Therefore, natural zeolites have the potential to reduce the $\mathrm{NaCl}$ in saline water at low cost for agricultural use. Japan is a volcanic country with abundant natural zeolite deposits, such as clinoptilolite and mordenite, and the development of natural zeolite utilization is an important issue for effective utilization of national resources. ${ }^{6}$ However, there has been little research published on the treatment of saline water with Japanese natural zeolites.

In this study, the desalination properties of five natural zeolites on seawater were examined to clarify the possibility of reducing salt in saline waters or salted soil in cultivated lands.

\section{Experimental}

\section{Seawater and samples}

Seawater used in this study was collected from the surface of Imari Bay, Saga Prefecture, Japan (Fig. S1 (Supporting Information)). The chemical composition and $\mathrm{pH}$ of the seawater are shown in Table 1 . The seawater contained high concentrations of $\mathrm{Na}^{+}(453.1 \mathrm{mM})$ and $\mathrm{Cl}^{-}(498 \mathrm{mM})$, and was $\mathrm{pH}$ neutral (8.0).

Five kinds of Japanese natural zeolites; Iizaka-zeolite (IZ), Tenkawachi-zeolite (TZ), Koriyama-zeolite (KZ), Futatsui-zeolite (FZ) and Niki-zeolite (NZ) were used in zeolite treatment. The occurrences and X-ray diffraction patterns of these natural zeolites are shown in Figs. S1 and S2 (Supporting Information), respectively. IZ and TZ were mordenite-type zeolites, and $\mathrm{KZ}$, FZ and NZ were clinoptilolite-type zeolites. These natural zeolites were typical of natural zeolite structures found all over the world.

\section{Natural zeolite treatment}

Natural zeolite samples used in this study were crushed, ground, sieved under $500 \mu \mathrm{m}$, and dried at $80^{\circ} \mathrm{C}$ for one day before use in experiments. A $20-\mathrm{g}$ amount of natural zeolite was added to $200 \mathrm{~mL}$ of seawater, and stirred for $2 \mathrm{~h}$ with a magnetic stirrer. After stirring, the slurry was filtered, and fresh natural zeolite was added to the filtrate. This procedure was repeated 10 times, and the $\mathrm{pH}$ of the filtrate and $\mathrm{Na}^{+}, \mathrm{K}^{+}$, $\mathrm{Mg}^{2+}, \mathrm{Ca}^{2+}, \mathrm{Cl}^{-}$and $\mathrm{SO}_{4}{ }^{2-}$ concentrations in the filtrate were determined after each zeolite treatment. This experiment was performed in triplicate to confirm reproducibility.

Table 1 Chemical compositions and $\mathrm{pH}$ of seawater

\begin{tabular}{ccccccc}
\hline \multicolumn{6}{c}{ Chemical composition/mM } & \multirow{2}{*}{$\mathrm{pH}$} \\
\cline { 1 - 6 } $\mathrm{Na}^{+}$ & $\mathrm{K}^{+}$ & $\mathrm{Mg}^{2+}$ & $\mathrm{Ca}^{2+}$ & $\mathrm{Cl}^{-}$ & $\mathrm{SO}_{4}{ }^{2-}$ & \\
\cline { 1 - 6 } 453.1 & 9.6 & 51.9 & 9.4 & 498.0 & 27.0 & 8.0 \\
\hline
\end{tabular}


Table 2 Exchangeable cations and cation exchange capacity of natural zeolites

\begin{tabular}{ccccccc}
\hline \multirow{2}{*}{ Sample } & $\begin{array}{c}\text { Type of } \\
\text { crystal }^{\mathrm{a}}\end{array}$ & \multicolumn{4}{c}{ Exchangeable cation/mmol g- } & \multicolumn{2}{c}{$\begin{array}{c}\mathrm{CEC} / \\
\mathrm{Nmol} \mathrm{g}^{-1}\end{array}$} & $\mathrm{Na}^{+}$ & $\mathrm{K}^{+}$ & $\mathrm{Mg}^{2+}$ & $\mathrm{Ca}^{2+}$ & \\
\hline IZ & Mor. & 0.56 & 0.21 & 0.03 & 0.44 & 1.67 \\
TZ & Mor. & 0.70 & 0.11 & 0.06 & 0.24 & 1.27 \\
KZ & Cli. & 0.58 & 0.28 & 0.02 & 0.40 & 1.51 \\
NZ & Cli. & 0.88 & 0.20 & 0.02 & 0.23 & 1.27 \\
FZ & Cli. & 0.84 & 0.71 & 0.02 & 0.07 & 1.67 \\
\hline
\end{tabular}

a. Mor., Mordenite-type zeolite; Cli., clinoptilolite-type zeolite.

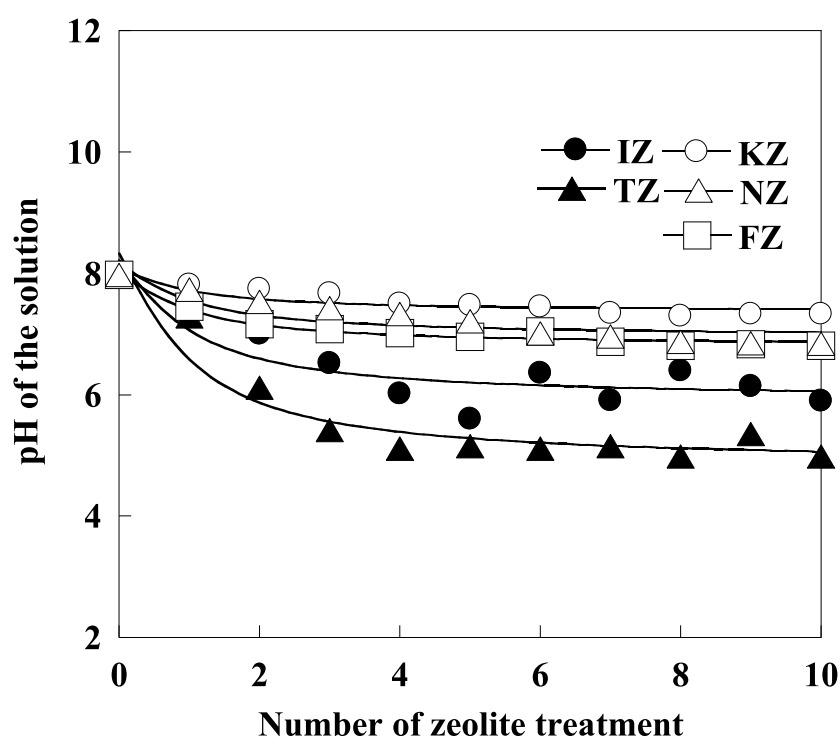

Fig. $1 \mathrm{pH}$ of the solution treated with various natural zeolites as a function of the number of natural zeolite treatments.

\section{Characterization}

The $\mathrm{pH}$ of the filtrate was measured with a pH meter (MA-130, Mettler-Toledo), and the concentrations of $\mathrm{Na}^{+}, \mathrm{K}^{+}, \mathrm{Mg}^{2+}, \mathrm{Ca}^{2+}$, $\mathrm{Cl}^{-}$and $\mathrm{SO}_{4}{ }^{2-}$ in the solution were determined using ion chromatography (DX-120, Japan Dionex). Exchangeable cations and cation exchange capacities of natural zeolites were measured by the modified Schorrenberg's method. ${ }^{6}$

\section{Results and Discussion}

Table 2 shows the exchangeable cations and cation exchange capacity (CEC) of natural zeolites. The CEC and composition of exchangeable cations of IZ and $\mathrm{KZ}$ were very similar. In addition, the CEC and composition of exchangeable cations of $\mathrm{TZ}$ and NZ were also similar. The CEC of IZ and $\mathrm{KZ}$ were higher than those of TZ and NZ. FZ had a high CEC, which was almost the same as IZ and KZ, but had a high content of exchangeable $\mathrm{K}^{+}$, which differed from IZ and $\mathrm{KZ}$.

Figure 1 shows the $\mathrm{pH}$ of the solution as a function of the number of zeolite treatments. The $\mathrm{pH}$ curves of the five samples were similar throughout treatment. The $\mathrm{pH}$ of the solution initially decreased for the first four treatments, and then remained constant after this point. After 10 treatment repetitions, the $\mathrm{pH}$ of all solutions were in the range of $5-8$, which is a feasible standard for agricultural use. Using mordenite-type samples, the solution $\mathrm{pH}$ decreased more noticeably than when using clinoptilolite-type samples.

Figure 2 shows the change in concentration of (a) $\mathrm{Na}^{+}$, (b) $\mathrm{K}^{+}$, (c) $\mathrm{Mg}^{2+}$, (d) $\mathrm{Ca}^{2+}$, (e) $\mathrm{Cl}^{-}$and (f) $\mathrm{SO}_{4}{ }^{2-}$ in the solution as a function of the number of natural zeolite treatments. $\mathrm{Na}^{+}$ concentration in seawater could be reduced by natural zeolite treatment, while the concentration of $\mathrm{Cl}^{-}$and $\mathrm{SO}_{4}{ }^{2-}$ ions barely changed, because zeolite is a cation exchanger. The solution treated with $\mathrm{IZ}$ and $\mathrm{KZ}$ indicate higher $\mathrm{Na}^{+}$reduction than those with TZ and NZ, because IZ and KZ have a higher CEC than TZ and NZ. IZ (mordenite-type zeolite) resulted in higher reduction of $\mathrm{Na}^{+}$ions than $\mathrm{KZ}$ (clinoptilolite-type zeolite). TZ (mordenite-type zeolite) also resulted in greater reduction of $\mathrm{Na}^{+}$ions than NZ (clinoptilolite-type zeolite). These reductions correlated closely with an increase in $\mathrm{Ca}^{2+}$ ions. The clinoptilolite-type zeolite indicated a higher reduction of $\mathrm{K}^{+}$and $\mathrm{Mg}^{2+}$ than mordenite-type zeolite. From these results, it is considered that the reduction of $\mathrm{Na}^{+}$mainly occurs by ion exchange between $\mathrm{Na}^{+}, \mathrm{K}^{+}$and $\mathrm{Mg}^{2+}$ in seawater and exchangeable $\mathrm{Ca}^{2+}$ in zeolite, with mordenite-type zeolites having higher selectivity of $\mathrm{Na}^{+}$than clinoptilolite-type zeolites. FZ has a high CEC, but the reduction of $\mathrm{Na}^{+}$is the worst among the five zeolite samples used. It is reported that the clinoptilolite has four cationic sites (M1, M2, M3 and M4) where ion exchange occurs, and M1, M2, M3 and M4 sites preferably occupy $\mathrm{Na}^{+}, \mathrm{K}^{+}, \mathrm{Ca}^{2+}$ and $\mathrm{Mg}^{2+}$, respectively. ${ }^{18,19}$ The preferential order of cation selectivity for clinoptilolites is $\mathrm{K}^{+}>\mathrm{NH}_{4}^{+}>$ $\mathrm{Na}^{+}>\mathrm{Ca}^{2+}>\mathrm{Mg}^{2+} \cdot 20$ It is considered that the exchangeable sites to reduce $\mathrm{Na}^{+}$(M1, M2 and M3) in FZ were occupied by $\mathrm{K}^{+}$before zeolite treatment, hence the amount of exchangeable sites available to reduce $\mathrm{Na}^{+}$in seawater was limited, although the CEC (number of exchangeable sites) of FZ is high. Additionally, for $\mathrm{Mg}^{2+}$ reduction, ion exchange between $\mathrm{Mg}^{2+}$ in seawater and $\mathrm{K}^{+}$at the exchangeable M4 site of the clinoptilolite competes with $\mathrm{Ca}^{2+}$ at the exchangeable M4 site. These results suggested that the best natural zeolite for the reduction of $\mathrm{Na}^{+}$in seawater is IZ, which is a mordenite-type zeolite with high CEC and exchangeable cation sites mainly occupied by $\mathrm{Ca}^{2+}$ available to exchange with $\mathrm{Na}^{+}$in seawater. It is noted that the $\mathrm{Ca}^{2+}$ released into seawater was not equal to the total reduction of $\mathrm{Na}^{2+}, \mathrm{K}^{+}$and $\mathrm{Mg}^{2+}$. It is unclear why there was a difference between the released amount of $\mathrm{Ca}^{2+}$ and the total reduced amount of cations in seawater. In this study, only main elements in seawater, $\mathrm{Na}^{+}, \mathrm{K}^{+}, \mathrm{Mg}^{2+}, \mathrm{Ca}^{2+}, \mathrm{Cl}^{-}$and $\mathrm{SO}_{4}{ }^{2-}$, were determined. However, other elements, such as $\mathrm{H}^{+}, \mathrm{Br}^{-}, \mathrm{CO}_{3}{ }^{2-}$ etc., also exist in seawater. It may be considered that subsidiary reactions occur during the ion exchange process using natural zeolite.

\section{Acknowledgements}

This study was performed under the Cooperative Research Program of the Institute of Ocean Energy, Saga University (11002A) and was supported by the Japan Society of Ion Exchange.

\section{References}

1. R. Semiat and D. Hasson, Rev. Chem. Eng., 2012, 28, 43.

2. J. Szytel, J. AWWA, 2005, 97, 54.

3. T. Goto, Suido-Kouron, 2000, 36, 43.

4. H. Tominaga, "Zeolite no Kagaku to Ouyou", 2001, Kodansha Corp., Tokyo.

5. M. Ohnuma, "Zeolite to Sono Riyou", 1967, Gihodou, 

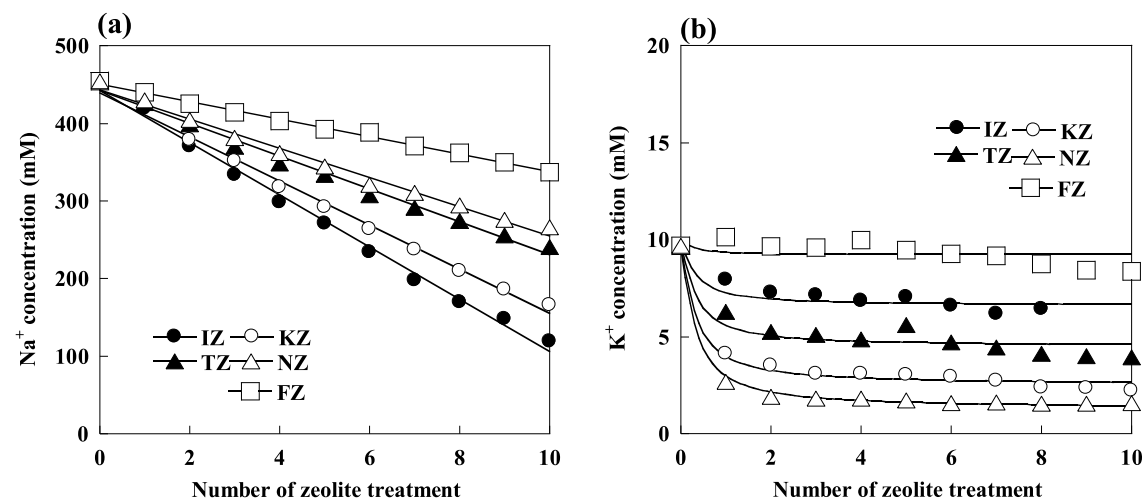

(c)
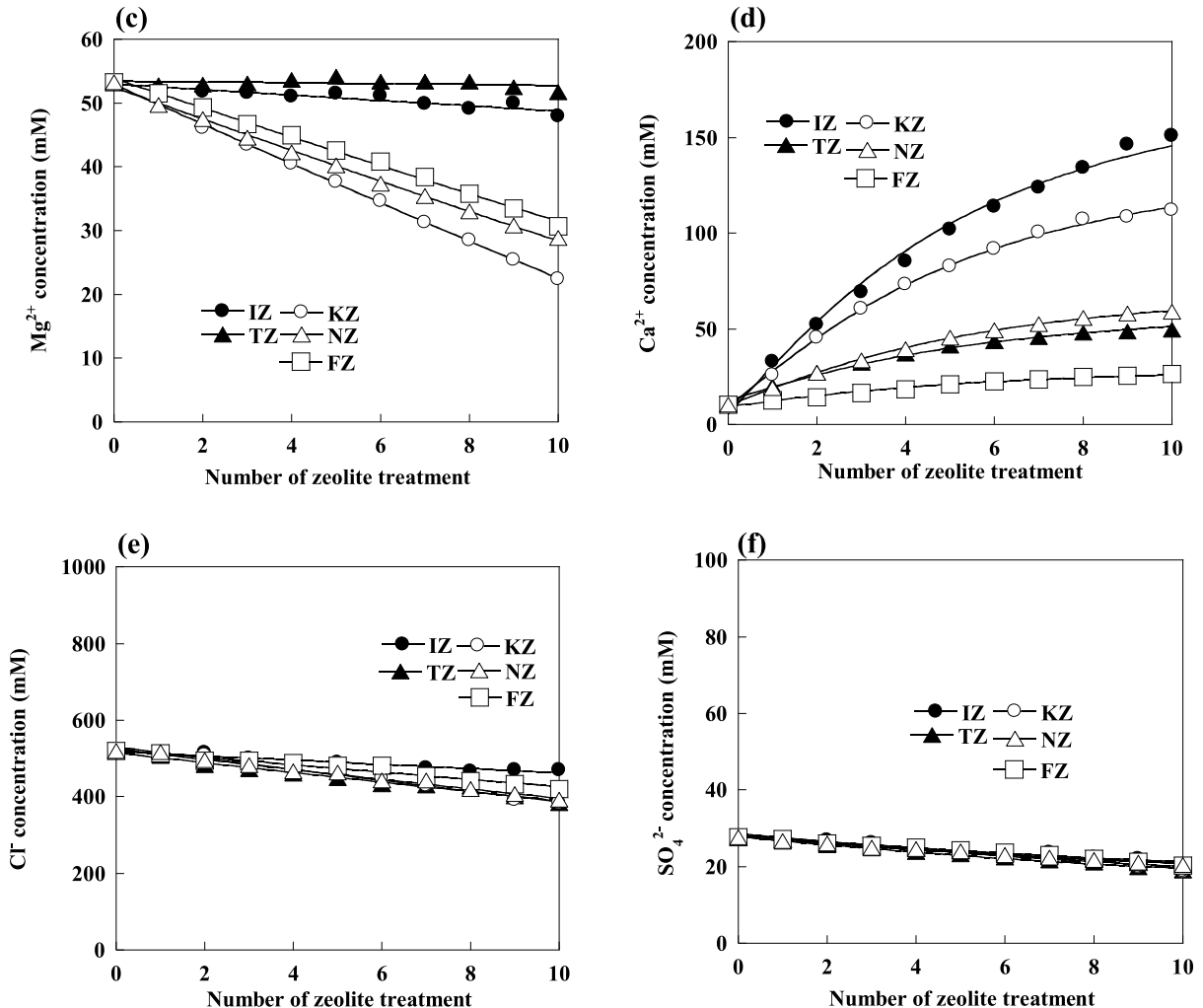

Fig. 2 Concentrations of (a) $\mathrm{Na}^{+}$, (b) $\mathrm{K}^{+}$, (c) $\mathrm{Mg}^{2+}$, (d) $\mathrm{Ca}^{2+}$, (e) $\mathrm{Cl}^{-}$and (f) $\mathrm{SO}_{4}{ }^{2-}$ in the solution treated with various natural zeolites as a function of the number of zeolite treatments.

Tokyo.

6. Development of New Utilization of Materials, "Natural Zeolite and Its Utilization", 1994, No. 111 Committee, Japan Society for the Promotion of Science, Tokyo.

7. R. A. Al Dwairi and A. E. Al-Rawajfeh, Recent Pat. Chem. Eng., 2012, 5, 20.

8. P. Misaelides, Microporous Mesoporous Mater., 2011, 144, 15.

9. S. Wang and Y. Peng, Chem. Eng. J., 2010, 156, 11.

10. S. Kesraoui-Ouki, C. R. Cheeseman, and R. Perry, J. Chem. Technol. Biotechnol., 1994, 59, 121.

11. W.-Y. Shi, H.-B. Shao, H. Li, M.-A. Shao, and S. Du, J. Hazard. Mater., 2009, 170, 1.

12. S. Montalvo, L. Guerrero, R. Borja, E. Sanchez, Z. Milan, I. Cortes, and M. A. Rubia, Appl. Clay Sci., 2012, 5, 20.

13. T. Wajima, T. Shimizu, and Y. Ikegami, Bull. Soc. Sea
Water Sci. Jpn., 2006, 60, 201.

14. T. Shimizu, T. Wajima, and Y. Ikegami, J. Ion Exch., 2007, 18, 390 .

15. T. Wajima, T. Shimizu, T. Yamato, and Y. Ikegami, Clay Sci., 2008, 14, 7.

16. T. Wajima, T. Shimizu, T. Yamato, and Y. Ikegami, J. Soc. Mater. Eng. Resour. Jpn., 2009, 1, 18.

17. T. Wajima, T. Shimizu, T. Yamato, and Y. Ikegami, Toxicol. Environ. Chem., 2010, 92, 21.

18. K. Koyama and Y. Takeushi, Zeit. Kryst., 1977, 145, 216.

19. D. W. Breck, "Zeolite Molecular Sieves", 1974, Wiley, New York.

20. A. Dyer, "Zeolites and Ordered Mesoporous Materials: Progress and Prospects", ed. J. Cejka and H. V. Bekkum, 2005, Vol. 157, Elsevier, Amsterdam, 181. 